\section{The Effect of Controlled-release Chlorine Dioxide on the Preservation of Grapefruit}

\author{
Xiuxiu Sun \\ U.S. Horticultural Research Laboratory, USDA, ARS, 2001 S. Rock Road, \\ Fort Pierce, FL 34945; and Indian River Research and Education Center, \\ University of Florida, 2199 S. Rock Rd Ft. Pierce, FL 34845
}

Elizabeth Baldwin, Chris Ference, Jan Narciso, and Anne Plotto U.S. Horticultural Research Laboratory, USDA, ARS, 2001 S. Rock Road, Fort Pierce, FL 34945

\author{
Mark Ritenour \\ 34945Indian River Research and Education Center, University of Florida, \\ 2199 S. Rock Road, Ft. Pierce, FL 34845
}

Ken Harrison and Dave Gangemi

Worrell Water Technologies, LLC, 4004 Hunterstand Court, Charlottesville, VA 22911

\section{Jinhe Bai ${ }^{1}$}

U.S. Horticultural Research Laboratory, USDA, ARS, 2001 S. Rock Road, Fort Pierce, FL 34945

Additional index words. antimicrobial activity, citrus canker, stem-end rot, decay, Escherichia coli

Abstract. The effect of controlled-release chlorine dioxide $\left(\mathrm{ClO}_{2}\right)$ gas on the safety and quality of grapefruit was studied. The experiments were run under controlled chamber systems with inoculated fruit, and in boxed fruit under commercial conditions. For the inoculation test, fruit artificially inoculated with either Escherichia coli or Penicillium digitatum, or naturally inoculated Xanthomonas citri ssp. citri (Xcc) (fruits with citrus canker lesions), were incubated in a chamber containing a dose equivalent to $0-60 \mathrm{mg} \cdot \mathrm{L}^{-1}$ of pure $\mathrm{ClO}_{2}$ as an antimicrobial agent. After 24 hours, the microbial population on treated grapefruit was significantly reduced compared with that of control fruit: a dosage of $5 \mathrm{mg} \cdot \mathrm{L}^{-1}$ completely inhibit the growth of $E$. coli and $P$. digitatum, but a dosage of $60 \mathrm{mg} \cdot \mathrm{L}^{-1}$ was needed to completely kill Xcc. For the simulated commercial experiment, fruit were harvested in late Oct. 2015 passed through a commercial packing line, and packed in $29 \mathrm{~L}$ citrus boxes. $\mathrm{ClO}_{2}$ packets were attached to the top lids with the following five treatments: fast-release, slow-release, slow/fast-release combination (each containing $14.5 \mathrm{mg} \cdot \mathrm{L}^{-1}$ of pure $\mathrm{ClO}_{2}$ ), double dose fast-release (containing $29 \mathrm{mg} \cdot \mathrm{L}^{-1}$ of $\mathrm{ClO}_{2}$ ), and control. After 6 weeks of storage at $10{ }^{\circ} \mathrm{C}$ (to simulate storage and transportation) +1 week of storage at $20^{\circ} \mathrm{C}$ (to simulate retail marketing), the fruit quality was evaluated. The slow-release treatment at standard dose exhibited the best antimicrobial activity, reducing total aerobic bacterial count and yeast/mold count by 0.95 and 0.94 log colony-forming units (cfu)/g of fruit, respectively, and maintained the best visual, sensory, and overall quality. However, the higher dosage treatments resulted in phytotoxicity as evidenced by peel browning.

Received for publication 21 Sept. 2016. Accepted for publication 31 Oct. 2016.

This paper is based on a presentation given during the 2016 Annual Meeting of the Florida State Horticultural Society, which was held June 12-14, 2016, in Stuart, FL.

We would like to thank the financial support provided by Worrell Water Technologies. Mention of a trademark or proprietary product is for identification only and does not imply a guarantee or warranty of the product by the U.S. Department of Agriculture. The U.S. Department of Agriculture prohibits discrimination in all its programs and activities on the basis of race, color, national origin, gender, religion, age, disability, political beliefs, sexual orientation, and marital or family status.

${ }^{1}$ Corresponding author. E-mail: jinhe.bai@ars.usda. gov.

Fresh produce is the main source of most foodborne illnesses in the United States, reported to the Centers for Disease Control and Prevention (CDC) (Herman et al., 2015). Between 2011 and 2013 the U.S. CDC reported 140 foodborne disease outbreaks associated with consumption of various contaminated foods. Many outbreaks of human gastroenteritis have been linked to the consumption of contaminated fresh vegetables and fruits (Garner and Kathariou, 2016). Enterotoxigenic E. coli, specifically serotype O157:H7, is the most common cause of diarrhea (Trainor et al., 2016), and consumption of $E$. coli $\mathrm{O} 157: \mathrm{H} 7$ contaminated cantaloupes caused an outbreak of gastroenteritis (Denis et al., 2016). Besides implementation of food safety plans with sound prerequisite programs and appropriate preventive controls for identified hazard to reduce the risk of foodborne infections, it is important to develop improved decontamination technologies for both food contact surfaces and the food itself. Furthermore, an estimated $24 \%$ of all fresh produce globally is lost postharvest due to microbial spoilage (Mahajan et al., 2014). Improved decontamination technology could also reduce surface microbial populations and subsequent postharvest spoilage.

Evidence from a large number of epidemiological studies, both in vitro and in vivo, has shown that consumption of citrus has many health benefits (Vanamala et al., 2006). Grapefruit (Citrus $\times$ paradisi) is a subtropical citrus fruit known for its sour to semisweet property (Murphy et al., 2014). Grapefruit juice contains high amounts of the flavanones naringenin and hesperetin, which exhibit estrogenic, anticarcinogenic, and antioxidative properties (Murphy et al., 2014; Reddy et al., 2007). However, grapefruit are susceptible to attack by the fungi $P$. digitatum Sacc and Penicillium italicum Wehmer, which cause green and blue molds, respectively, and account for most of the postharvest losses of citrus fruits worldwide (Louw and Korsten, 2015). Although not causing fruit decay, citrus canker, caused by the pathogenic bacterium $X$. citri ssp. citri $(X c c)$, is another serious disease affecting grapefruit production in several tropical and subtropical areas of the world (Bock et al., 2011).

$\mathrm{ClO}_{2}$ is a water-soluble oxidizer with an oxidation capacity 2.5 times greater than that of free chlorine (Sun et al., 2014; Wang et al., 2014). It has been used in postharvest processes to reduce microbial populations on fruits and vegetables in both aqueous and gaseous forms (Gomez-Lopez et al., 2009; Sun et al., 2014; Sy et al., 2005a). However, the instability of aqueous $\mathrm{ClO}_{2}$ and the equipment requirements for on-site production of gaseous $\mathrm{ClO}_{2}$ have limited its application (Chomkitichai et al., 2014). Curoxin ${ }^{\circledR} \mathrm{ClO}_{2}\left(9.5 \%\right.$ w/w $\mathrm{ClO}_{2}$ slurry, Worrell Water Technologies, Charlottesville, VA) is stable, ready-to-use, and available in an easily transportable form. Due to its proprietary microencapsulation, the release of $\mathrm{ClO}_{2}$ gas can be regulated, providing sustained delivery of $\mathrm{ClO}_{2}$ for improved disinfection and reduced spoilage.

Nevertheless, to the best of our knowledge, no information related to the effect of controlled-release $\mathrm{ClO}_{2}$ on the safety and quality of grapefruit has been conducted to date. The objective of this research was to evaluate an advanced form of $\mathrm{ClO}_{2}$ (Curoxin ${ }^{\circledR}$ $\mathrm{ClO}_{2}$ ) delivered in sealed pouches with selectable release rates for use in eliminating pathogens and extending shelf life of grapefruit.

\section{Materials and Methods}

Fruits. Grapefruit (Citrus ×paradisi, var. Ruby Red), grown in Vero Beach, FL, were used for all experiments. For the chamber inoculation experiment, defect free, and diseased fruits with canker lesions, 20 fruit per treatment, were obtained from an experimental 
block on Nov. 23,2015 , and stored at $10{ }^{\circ} \mathrm{C}$ for 1-7 $\mathrm{d}$ before fruit inoculation and incubation. To simulated commercial storage/transportation/marketing conditions, fruit harvested from a commercial field in Oct. 2015 were passed through a commercial packing line and 56 fruits (average fruit weight $260 \mathrm{~g}$ and diameter $85 \mathrm{~mm}$ ) were packed in each of 15, 29-L commercial perforated boxes that were then stored at $10{ }^{\circ} \mathrm{C}$ for $3 \mathrm{~d}$ before applying $\mathrm{ClO}_{2}$ treatments.

Chamber test with microbial inoculated fruit. Strains of $E$. coli wild type and $P$. digitatum wild type were isolated from citrus fruit surfaces (Narciso et al., 2012) and stored at $-80{ }^{\circ} \mathrm{C}$ on EC agar (ECA) made by EC Broth (Oxoid, UK) with $1.5 \%$ agar, and on potato dextrose agar (PDA, BD Difco, Sparks, MD) plugs in $10 \%$ glycerol (cryoprotectant), respectively. The ECA plugs were recultured on ECA at $35^{\circ} \mathrm{C}$ for a week and the bacteria were checked on Levine eosin methylene blue (EMB) agar. The PDA plugs were recultured on PDA at $25^{\circ} \mathrm{C}$ for a week and identified by spore production. For inoculum preparation, the $E$. coli and $P$. digitatum cells and spores were scraped from $4 \mathrm{~d}$ and $7 \mathrm{~d}$ old cultures on ECA and PDA media, respectively, using a sterile loop with a drop of $0.1 \%$ Tween20 (Fisher Scientific Inc., Pittsburgh, PA), to aid in even spore suspension. Cells/spores were suspended into $2 \mathrm{~L}$ of sterile distilled water at room temperature for inoculation at populations of 7.29 and $7.56 \mathrm{log} / \mathrm{mL}$ for $E$. coli and $P$. digitatum, respectively.

The fruit were completely submerged in the inoculum for $30 \mathrm{~s}$ and then placed onto an open shelf and allowed to dry for $2 \mathrm{~h}$ at $20 \pm$ $2{ }^{\circ} \mathrm{C}$ in a biosafety flow hood.

Individual inoculated fruit were incubated in a glass chamber containing a dose equivalent to 5,10 , or $15 \mathrm{mg} \cdot \mathrm{L}^{-1}$ of gaseous $\mathrm{ClO}_{2}$ at $20{ }^{\circ} \mathrm{C}$ for $24 \mathrm{~h}$, and microbial survival was detected. For the Xcc test, naturally infected fruit with visible canker lesions were incubated under the same conditions as above except the $\mathrm{ClO}_{2}$ dosage was increased to $0,20,40$, or 60 $\mathrm{mg} \cdot \mathrm{L}^{-1}$ based on a preliminary experiment. All treatments included three replicates.

Boxed fruit under simulated commercial conditions. The $\mathrm{ClO}_{2}$ packets were prepared using heat sealing plastic films containing $0.5 \mathrm{~g}$ Curoxin ${ }^{\circledR} \mathrm{ClO}_{2}$ slurry (9.5\% a.i.). The slow and fast releases were regulated by selecting films with different $\mathrm{ClO}_{2}$ permeance. The effective surface area was $6 \mathrm{~cm}^{2}$. The packets were attached on the top lids of the boxes with double-sided tape and the following five treatments were applied: single dose fast-release (two packets, F), single dose slow-release (two packets, S), combination of single dose slowand single dose fast-release (one packet for each type, FS), double dose fast-release (four packets, FF), and non- $\mathrm{ClO}_{2}$ control (C). Each treatment contained three replicates, and each replicate contained 56 fruits in one box. After $42 \mathrm{~d}$ storage at $10{ }^{\circ} \mathrm{C}$ (to simulate storage and transportation) $+7 \mathrm{~d}$ storage at $20{ }^{\circ} \mathrm{C}$ (to simulate retail market), each box (replicate) was unpacked, and the fruit were evaluated for visual quality, peel disorders (browning), stem-end rot, sensory quality, and microbial populations.

Microbiological analysis. Under sterile conditions, fruit samples (one from each replicate) were agitated for $1 \mathrm{~h}$ in a sterilized sampling bag (Fisherbrand, Fisher Scientific, Pittsburgh, PA) along with $99 \mathrm{~mL}$ of sterile potassium phosphate buffer $(0.01 \mathrm{M}, \mathrm{pH} 7.2)$ on an orbital shaker (Innova 2100; New Brunswick Scientific, New Brunswick, NJ). A dilution series were prepared and cultured on different media for microbial counts. ECA media was used for enumerating E. coli, PDA for enumerating yeast/mold, nutrient agar (NA, BD Difco, Sparks, MD) for enumerating $X c c$, and plate count agar (PCA, BD Difco, Sparks, MD) for enumerating total bacteria count using an Eddy Jet Spiral Plater (Neutec Group Inc., Farmingdale, NY). ECA, PDA, $\mathrm{NA}$, and PCA were incubated at $35{ }^{\circ} \mathrm{C}$ for $24 \mathrm{~h}, 25^{\circ} \mathrm{C}$ for $3 \mathrm{~d}, 35^{\circ} \mathrm{C}$ for $24 \mathrm{~h}$, and $25^{\circ} \mathrm{C}$ for $2 \mathrm{~d}$, respectively (Ruparelia et al., 2008; Sun et al., 2014), and the results were read on a ProtoCOL colony counter (Synoptics, Ltd., Cambridge, UK). Fungal and bacterial populations were expressed as log cfu/gram of fruit. All tests were run in triplicate.

Visual quality evaluation. The overall visual quality, peel browning, and incidence of stem-end rot were evaluated for individual fruit in the commercial citrus box. Fruit visual quality was subjectively scored using a 1-9 scale $(9=$ excellent, $7=$ good, $5=$ fair, $3=$ poor, and $1=$ completely deteriorated) (Bai et al., 2003). A score of 5 was considered the threshold level for marketability, and 3 for edibility. All criteria were then normalized to a scale of $0-1$ (worst-best) by feature scaling (Aksoy and Haralick, 2001) for average fruit quality in each treatment. Percentage of peel browning and incidence of stem-end rot were calculated by the total number of fruit exhibiting peel browning or stem-end rot symptoms. Fifty six fruit were evaluated individually per replicate and the percentage was used for data analysis. Every treatment includes three replicates.

Sensory evaluation. Sensory evaluation was carried out with fresh-cut grapefruit from the commercial citrus box by a panel of 10 staff members using a $1-5$ index scale $(1=$ none and $5=$ strong) testing for moldy offflavor, chemical or other off-flavor, juiciness, and overall quality (Bai et al., 2011). All panel members were familiar with sensory evaluation of grapefruit and other fruits. Every panel member was presented with two 3-digit coded samples, one for each of slow-release $\mathrm{ClO}_{2}$-treated and untreated control.

Weight loss. To determine weight loss, fruit in the commercial citrus box were weighed at the beginning and during storage. Weight loss was expressed as the percentage loss of the initial total weight.

Statistical analyses. All experiments were replicated at least three times. Data were analyzed using analysis of variance with SPSS, version 17.0 software (Experian QAS, Boston, MA). Mean separation was determined by Duncan's multiple range test. Significance was defined at $P<0.05$.

\section{Results and Discussion}

In the chamber experiment, microbial growth was significantly inhibited compared with the control, and the lowest concentration of $\mathrm{ClO}_{2}\left(5 \mathrm{mg} \cdot \mathrm{L}^{-1}\right)$ completely inhibited the growth of E. coli and $P$. digitatum. Dosages of $20 \mathrm{mg} \cdot \mathrm{L}^{-1}$ and $40 \mathrm{mg} \cdot \mathrm{L}^{-1}$ reduced the population of $X c c$ by 2.44 and $6.45 \operatorname{logs}$, respectively, compared with the control and the dosage of $60 \mathrm{mg} \cdot \mathrm{L}^{-1}$ completely inhibited the growth of $X c c$ (Table 1). $\mathrm{ClO}_{2}$ has broad antimicrobial efficiency against many pathogenic and spoilage microorganisms, such as E. coli O157:H7, Salmonella sp., Penicillium expansum, and Xanthomonas campestris pv. campestris (Krauthausen et al., 2011; Mahmoud et al., 2008; Okull et al., 2006). It reduces microorganism populations by oxidation, mainly through the one-electron transfer mechanism, in which the compound itself is reduced to chlorite (Netramai et al., 2012). Treatment with $200 \mu \mathrm{g} \cdot \mathrm{mL}^{-1} \quad \mathrm{ClO}_{2}$ for 10 min showed greater lethal activity than $\mathrm{NaOCl}$ applied at the same concentration for the same duration against $E$. coli $\mathrm{O} 157: \mathrm{H} 7$ in a biofilm (Bang et al., 2014). The mode of action of $\mathrm{ClO}_{2}$ on $E$. coli is thought to be due to the loss of potassium membrane permeability control, along with nonspecific oxidative damage to the outer membrane, all leading to the destruction of the transmembrane ionic gradient (Berg et al., 1986). Inoculum of $P$. digitatum in a commercial soak tank was reduced by maintaining $5-10$ $\mathrm{mg} \cdot \mathrm{L}^{-1}$ of available $\mathrm{ClO}_{2}$ in the tank (Brown and Wardowski, 1984). A concentration of $3 \mathrm{mg} \cdot \mathrm{L}^{-1} \mathrm{ClO}_{2}$ was effective against $X$. campestris pv. campestris in brassica transplants (Krauthausen et al., 2011). These results indicate that $\mathrm{ClO}_{2}$ can be used as an antimicrobial agent against certain microorganisms.

In the simulated commercial experiment, the slow-release treatment at standard dose reduced yeast/mold, and total bacterial count compared with the control by 0.94 and 0.95 $\operatorname{logs} \mathrm{cfu} / \mathrm{g}$, respectively (Table 2). Similar results have been reported with treatments of 60 and $80 \mathrm{mg} \cdot \mathrm{L}^{-1}$ of aqueous $\mathrm{ClO}_{2}$ in mulberry fruit, where the population of aerobic

Table 1. Effects of $\mathrm{ClO}_{2}$ on microbial populations on individual grapefruit after inoculation with either Escherichia coli or Penicillium digitatum, and then incubation at $20{ }^{\circ} \mathrm{C}$ for $24 \mathrm{~h}$ in individual chambers. Populations of Xanthomonas citri $(X c c)$ were also evaluated but came from natural infection in the field. Microbial count is expressed as $\log$ colony-forming units (cfu)/g.

\begin{tabular}{lccc}
\hline $\begin{array}{l}\mathrm{ClO}_{2} \text { concn } \\
\left(\mathrm{mg} \cdot \mathrm{L}^{-1}\right)\end{array}$ & $\begin{array}{c}\text { E. coli } \\
(\log \mathrm{cfu} / \mathrm{g})\end{array}$ & $\begin{array}{c}\text { P. digitatum } \\
(\log \mathrm{cfu} / \mathrm{g})\end{array}$ & $\begin{array}{c}\text { Xcc } \\
(\log \mathrm{cfu} / \mathrm{g})\end{array}$ \\
\hline 0 & $5.31 \mathrm{a}^{\mathrm{z}}$ & $5.30 \mathrm{a}$ & $7.92 \mathrm{a}$ \\
5 & $0 \mathrm{~b}$ & $0 \mathrm{~b}$ & \\
10 & $0 \mathrm{~b}$ & $0 \mathrm{~b}$ & \\
15 & $0 \mathrm{~b}$ & $0 \mathrm{~b}$ & $5.48 \mathrm{~b}$ \\
20 & & & $1.47 \mathrm{c}$ \\
40 & & & $0 \mathrm{~d}$ \\
60 & & & \\
\hline${ }^{\mathrm{z}}$ Mean values followed by different letters within
\end{tabular}

a column indicate significant differences using Duncan test $(P<0.05)$. 
Table 2. Effects of $\mathrm{ClO}_{2}$ on microbial populations on grapefruit held under commercial conditions (storage at $10{ }^{\circ} \mathrm{C}$ for $42 \mathrm{~d}+20{ }^{\circ} \mathrm{C}$ for $7 \mathrm{~d}$ ), expressed in log colony-forming units (cfu)/g.

\begin{tabular}{lcc}
\hline Treatment & $\begin{array}{c}\text { Yeast } / \mathrm{mold} \\
(\log \mathrm{cfu} / \mathrm{g})\end{array}$ & $\begin{array}{c}\text { Total bacteria } \\
(\log \mathrm{cfu} / \mathrm{g})\end{array}$ \\
\hline $\mathrm{C}$ & $5.90 \mathrm{a}^{\mathrm{z}}$ & $6.11 \mathrm{a}$ \\
$\mathrm{F}$ & $5.06 \mathrm{~b}$ & $5.40 \mathrm{ab}$ \\
$\mathrm{S}$ & $4.96 \mathrm{~b}$ & $5.16 \mathrm{~b}$ \\
$\mathrm{FS}$ & $5.08 \mathrm{~b}$ & $5.38 \mathrm{ab}$ \\
$\mathrm{FF}$ & $5.01 \mathrm{~b}$ & $5.35 \mathrm{ab}$ \\
\hline
\end{tabular}

$\mathrm{C}=$ control, $\mathrm{F}=$ single fast-release, $\mathrm{S}=$ single slowrelease, $\mathrm{FS}=$ single fast/slow combination, and $\mathrm{FF}=$ double fast-release.

${ }^{\mathrm{z}}$ Mean values followed by different letters within a column indicate significant differences using Duncan test $(P<0.05)$.

mesophilic bacteria, aerobic psychrotrophic bacteria, lactic acid bacteria, and yeast and mold were significantly reduced (Chen et al., 2011). In addition, a gaseous treatment with $12.0 \mathrm{mg} \cdot \mathrm{L}^{-1}$ for $10 \mathrm{~min}, 7.2 \mathrm{mg} \cdot \mathrm{L}^{-1}$ for $20 \mathrm{~min}$, or $4.8 \mathrm{mg} \cdot \mathrm{L}^{-1}$ for $30 \mathrm{~min}$ of $\mathrm{ClO}_{2}$ at $21{ }^{\circ} \mathrm{C}$ and $90 \%$ to $95 \%$ relative humidity completely inactivated $8 \log \mathrm{cfu} /$ site of $E$. coli $\mathrm{O} 157: \mathrm{H} 7$ that had been initially inoculated on apple skin (Du et al., 2003). Treatments with 0.62 and $1.24 \mathrm{mg} \cdot \mathrm{L}^{-1} \mathrm{ClO}_{2}$ gas for $30 \mathrm{~min}$ at $22{ }^{\circ} \mathrm{C}$ and $90 \%$ to $95 \%$ relative humidity reduced $E$. coli $\mathrm{O} 157: \mathrm{H} 7 \times 3.03$ and $6.45 \mathrm{log}$, respectively, on surface-injured green peppers (Han et al., 2000). Total aerobic bacteria, yeasts and molds on strawberries were significantly inhibited by $50 \mathrm{ppm}$ of aqueous $\mathrm{ClO}_{2}$ (Jin et al., 2007). It was concluded that $\mathrm{ClO}_{2}$, both in gaseous and aqueous forms, was a promising antimicrobial agent for fresh fruits and vegetables.

Along with the control, fruit exposed to the "slow" $\mathrm{ClO}_{2}$ treatment maintained relatively high overall visual quality, and were significantly better than fruit exposed to the double fast-release $\mathrm{ClO}_{2}$ treatment (Fig. 1A). The percentage of marketable fruit (score $\geq 5$ ) under "slow" $\mathrm{ClO}_{2}$ treatment was $89.3 \%$, which is higher than that of fast/slow combination $(76.2 \%)$ or double fast-release $(61.3 \%)$ treatment (Fig. 1B). There was high incidence of chemical burn in the double fast-release treatment, although this treatment showed the best control of stem-end rot, whereas the "slow" $\mathrm{ClO}_{2}$ treatment was next most effective with no browning (Fig. 2). However, there was no significant chemical burn detected on fruit receiving the "slow" $\mathrm{ClO}_{2}$ treatment.

Appearance is one of the most important factors influencing consumer acceptance of fruits and vegetables (Bai et al., 2011). Browning is generally produced by the oxidation of phenols into quinones that subsequently polymerize into brown pigments (melanins), a reaction catalyzed by polyphenol oxidase (Gomez-Lopez, 2002). Gaseous $\mathrm{ClO}_{2}$ can immediately induce browning of cabbage (Sy et al., 2005b). The results in the present research suggest a similar effect of the $\mathrm{ClO}_{2}$ resulting in browning. Diplodia stem-end rot of citrus fruits, caused by the fungus Lasiodiplodia theobromae, is a typical postharvest disease in Florida and other subtropical and
A

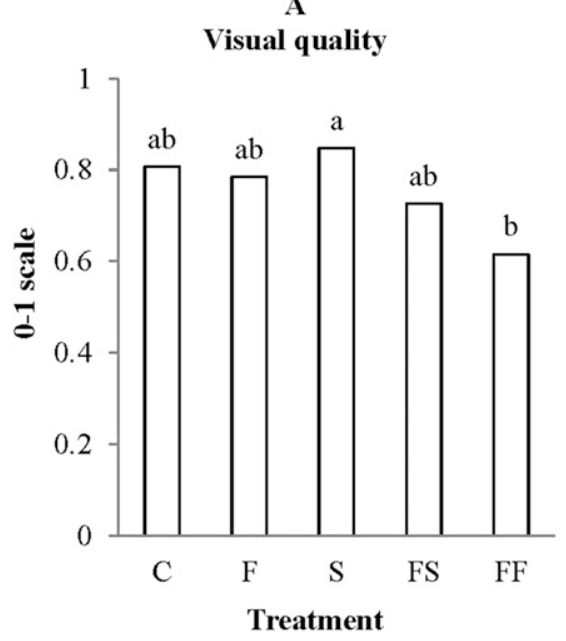

B

Percent marketable

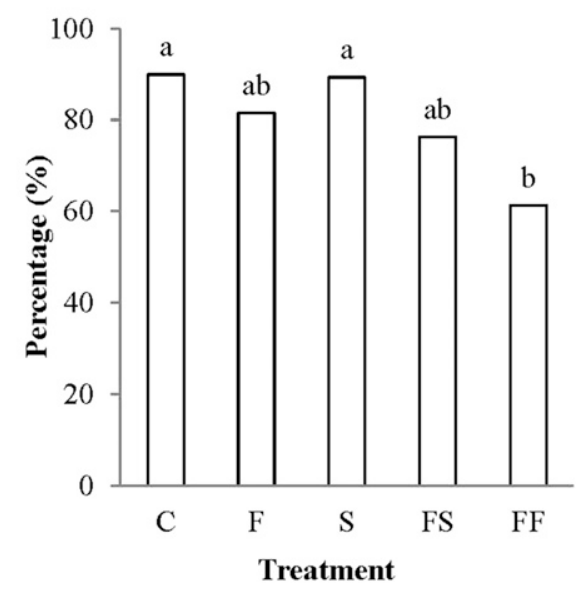

Fig. 1. Effects of $\mathrm{ClO}_{2}$ on overall visual quality of grapefruit held under commercial conditions (storage at $10{ }^{\circ} \mathrm{C}$ for $42 \mathrm{~d}+20^{\circ} \mathrm{C}$ for $7 \mathrm{~d}$ ). Fruit visual quality (A) was subjectively scored using a $1-9$ scale $(9=$ excellent, $7=$ good, $5=$ fair, $3=$ poor, and $1=$ completely deteriorated). The average fruit quality in each treatment was normalized to a $0-1$ scale. The percentages of marketable fruits (B, quality scale higher or equal to 5) was calculated. $\mathrm{C}=$ control, $\mathrm{F}=$ single fast-release, $\mathrm{S}=$ single slow-release, $\mathrm{FS}=$ single fast/slow combination, and $\mathrm{FF}=$ double fast-release. Bars with different letters within each number indicate significant differences using Duncan test $(P<0.05)$.

A

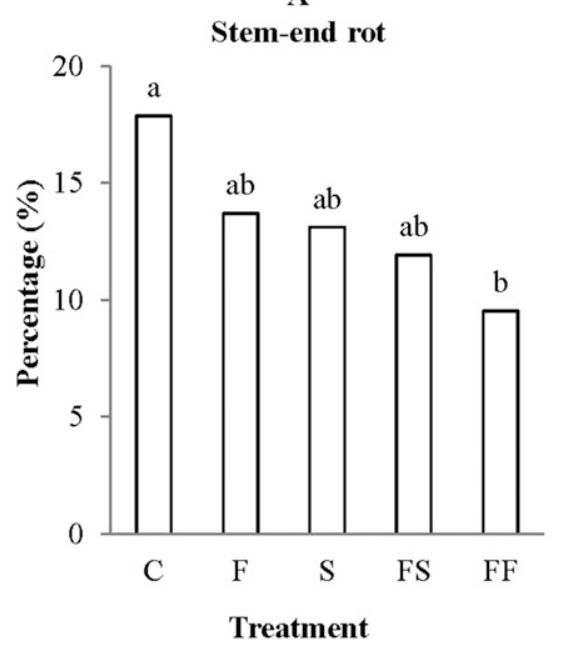

B

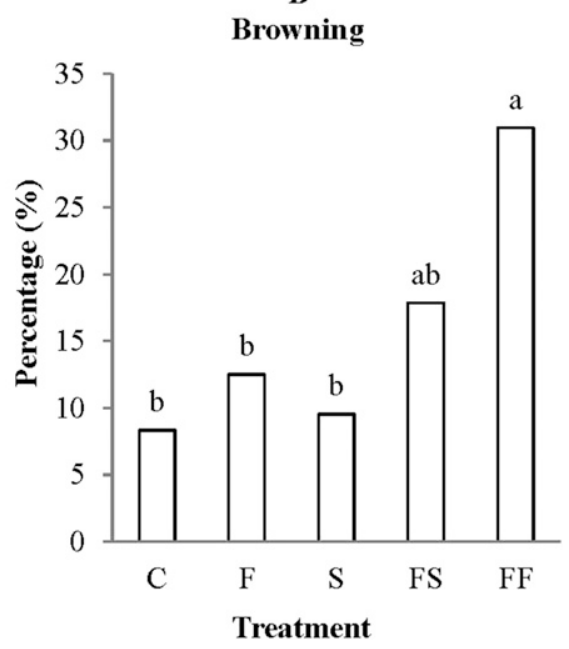

Fig. 2. Effects of $\mathrm{ClO}_{2}$ on incidence stem-end $\operatorname{rot}(\mathbf{A})$ and phytotoxicity browning (B) visual quality of grapefruit held under commercial conditions (storage at $10^{\circ} \mathrm{C}$ for $42 \mathrm{~d}+20{ }^{\circ} \mathrm{C}$ for $7 \mathrm{~d}$ ), expressed in percentage $(\%) . \mathrm{C}=$ control, $\mathrm{F}=$ single fast-release, $\mathrm{S}=$ single slow-release, $\mathrm{FS}=$ single fast/slow combination, and $\mathrm{FF}=$ double fast-release. Bars with different letters within stem-end rot or browning indicate significant differences using Duncan test $(P<0.05)$.

tropical regions (Zhao et al., 2015). $\mathrm{ClO}_{2}$ gas has potential as a postinoculation treatment of tomatoes for prevention of bacterial soft rot (Mahovic et al., 2007). Phytotoxic bleaching caused by $\mathrm{ClO}_{2}$ gas has been detected in lettuce leaves after 15 -min exposure to 0.75 $\mathrm{mg} \cdot \mathrm{L}^{-1} \mathrm{ClO}_{2}$ (Singh et al., 2002). This may be due to the oxidation of chlorophyll during longer exposure times at higher concentrations of $\mathrm{ClO}_{2}$. No color change was observed when milder treatment conditions were applied (Gomez-Lopez et al., 2009; Singh et al., 2002). These results, which agree with our own, suggest that a low concentration of $\mathrm{ClO}_{2}$ will likely not cause adverse effects to the appearance of fresh fruits and vegetables.
Since the "slow" $\mathrm{ClO}_{2}$ treatment showed the most promising results for visual quality, marketability, and control of stem-end rot without phototoxicity, a sensory test was done to determine if this treatment caused adverse sensory effects.

Fruit exposed to the "slow" $\mathrm{ClO}_{2}$ treatment demonstrated better sensory quality by maintaining significantly higher juiciness and overall quality than for control (Fig. 3). Lee et al. (2012) evaluated the effects of aqueous $\mathrm{ClO}_{2}$ and ultraviolet-C on the sensory properties of Romaine lettuce and kale and found the treatment provided better scores than the control. In addition, fresh-cut lettuce washed in a $3 \mathrm{mg} \cdot \mathrm{L}^{-1}$ aqueous $\mathrm{ClO}_{2}$ did not adversely 


\section{Sensory evaluation}

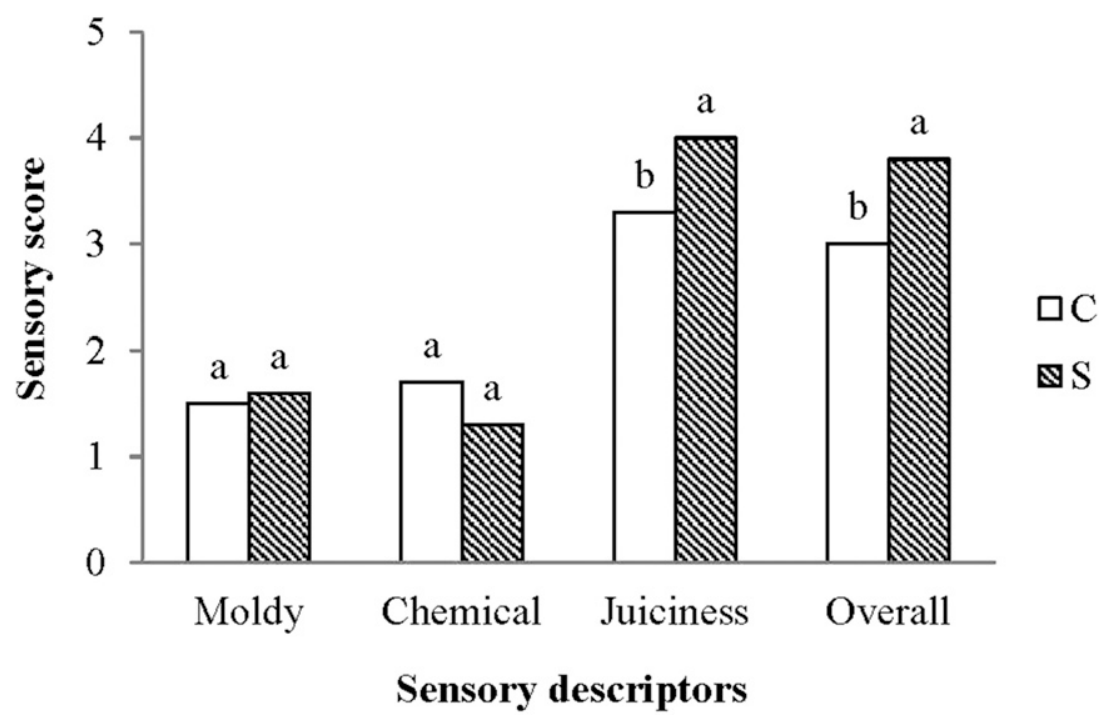

Fig. 3. Effects of $\mathrm{ClO}_{2}$ on sensory quality of grapefruit held under commercial conditions (storage at $10{ }^{\circ} \mathrm{C}$ for $42 \mathrm{~d}+20^{\circ} \mathrm{C}$ for $\left.7 \mathrm{~d}\right)$. A $1-5$ index scale $(1=$ none and $5=$ strong $)$ was used for the sensory evaluation with descriptors of moldy off-flavor (moldy), chemical or other off-flavor (chemical), juiciness, and overall quality. $\mathrm{C}=$ control and $\mathrm{S}=$ single slow-release. Bars with different letters within a descriptor indicate significant differences using Duncan test $(P<0.05)$.

affect sensory quality (Lopez-Galvez et al., 2010). Similarly, aqueous $\mathrm{ClO}_{2}$ treatment did not damage blueberries (Rodgers et al., 2004). $\mathrm{ClO}_{2}$ treatments did not cause any significant weight loss in this research (data not shown).

In conclusion, $\mathrm{ClO}_{2}$ could be used as a sanitizer on grapefruit to reduce surface microbial populations including $E$. coli, citrus canker bacterium $(X c c)$ and fungal pathogen $P$. digitaum. $\mathrm{ClO}_{2}$ also reduced stem-end rot incidence on grapefruit. The findings in this study suggest that a slow-release $\mathrm{ClO}_{2}$ treatment in active packaging could improve the microbial safety, quality, and taste of grapefruit while reducing decay during storage and without impairing the appearance. This information contributes to increasing knowledge regarding the impact of controlled-release $\mathrm{ClO}_{2}$ on food safety and quality and its potential use at commercial level.

\section{Literature Cited}

Aksoy, S. and R.M. Haralick. 2001. Feature normalization and likelihood-based similarity measures for image retrieval. Pattern Recognit. Lett. 22:563-582.

Bai, J.H., A. Plotto, R. Spotts, and N. Rattanapanone. 2011. Ethanol vapor and saprophytic yeast treatments reduce decay and maintain quality of intact and fresh-cut sweet cherries. Postharvest Biol. Technol. 62:204-212.

Bai, J.H., R.A. Saftner, and A.E. Watada. 2003. Characteristics of fresh-cut honeydew (Cucumis xmelo L.) available to processors in winter and summer and its quality maintenance by modified atmosphere packaging. Postharvest Biol. Technol. 28:349-359.

Bang, J., A. Hong, H. Kim, L.R. Beuchat, M.S. Rhee, Y. Kim, and J.H. Ryu. 2014. Inactivation of Escherichia coli $\mathrm{O} 157: \mathrm{H} 7$ in biofilm on food-contact surfaces by sequential treatments
Han, Y., D.M. Sherman, R.H. Linton, S.S. Nielsen, and P.E. Nelson. 2000. The effects of washing and chlorine dioxide gas on survival and attachment of Escherichia coli O157: H7 to green pepper surfaces. Food Microbiol. 17:521-533.

Herman, K.M., A.J. Hall, and L.H. Gould. 2015. Outbreaks attributed to fresh leafy vegetables, United States, 1973-2012. Epidemiol. Infect. 143:3011-3021.

Jin, Y.Y., Y.J. Kim, K.S. Chung, M. Won, and K. Bin Song. 2007. Effect of aqueous chlorine dioxide treatment on the microbial growth and qualities of strawberries during storage. Food Sci. Biotechnol. 16:1018-1022.

Krauthausen, H.J., N. Laun, and W. Wohanka. 2011. Methods to reduce the spread of the black rot pathogen, Xanthomonas cam pestris pv. campestris, in brassica transplants. J. Plant Dis. Prot. 118:7-16.

Lee, J.H., H.H. Chun, D.H. Oh, J. Park, M. Won, and K.B. Song. 2012. Sensory and microbiological qualities of romaine lettuce and kale affected by a combined treatment of aqueous chlorine dioxide and ultraviolet-C. Hort. Environ. Biotechnol. 53:387-396.

Lopez-Galvez, F., A. Allende, P. Truchado, A. Martinez-Sanchez, J.A. Tudela, M.V. Selma, and M.I. Gil. 2010. Suitability of aqueous chlorine dioxide versus sodium hypochlorite as an effective sanitizer for preserving quality of fresh-cut lettuce while avoiding by-product formation. Postharvest Biol. Technol. 55: 53-60.

of aqueous chlorine dioxide and drying. Intl. J. Food Microbiol. 191:129-134.

Berg, J.D., P.V. Roberts, and A. Matin. 1986. Effect of chlorine dioxide on selected membrane functions of Escherichia-coli. J. Appl. Bacteriol. 60:213-220.

Bock, C.H., T.R. Gottwald, and P.E. Parker. 2011. Distribution of canker lesions on the surface of diseased grapefruit. Plant Pathol. 60:986-991.

Brown, G.E. and W.F. Wardowski. 1984. Use of chlorine and chlorine dioxide in Florida citrus packinghouses to reduce inoculum of decay pathogens. Proc. Fla State Hort. Soc 97:97100.

Chen, Z., C.H. Zhu, and Z.Q. Han. 2011. Effects of aqueous chlorine dioxide treatment on nutritional components and shelf-life of mulberry fruit (Morus alba L.). J. Biosci. Bioeng. 111:675-681.

Chomkitichai, W., B. Faiyue, P. Rachtanapun, J. Uthaibutra, and K. Saengnil. 2014. Enhancement of the antioxidant defense system of postharvested 'Daw' longan fruit by chlorine dioxide fumigation. Sci. Hort. 178:138-144.

Denis, N., H. Zhang, A. Leroux, R. Trudel, and H. Bietlot. 2016. Prevalence and trends of bacterial contamination in fresh fruits and vegetables sold at retail in Canada. Food Control 67:225234.

Du, J., Y. Han, and R.H. Linton. 2003. Efficacy of chlorine dioxide gas in reducing Escherichia coli O157: H7 on apple surfaces. Food Microbiol. 20:583-591.

Garner, D. and S. Kathariou. 2016. Fresh produceassociated listeriosis outbreaks, sources of concern, teachable moments, and insights. J. Food Prot. 79:337-344.

Gomez-Lopez, V.M. 2002. Some biochemical properties of polyphenol oxidase from two varieties of avocado. Food Chem. 77:163-169.

Gomez-Lopez, V.M., A. Rajkovic, P. Ragaert, N. Smigic, and F. Devlieghere. 2009. Chlorine dioxide for minimally processed produce preservation: A review. Trends Food Sci. Technol. 20:17-26.
Louw, J.P. and L. Korsten. 2015. Pathogenicity and host susceptibility of penicillium spp. on citrus. Plant Dis. 99:21-30.

Mahajan, P.V., O.J. Caleb, Z. Singh, C.B. Watkins, and M. Geyer. 2014. Postharvest treatments of fresh produce. Philos. Trans. A Math. Phys. Eng. Sci. 372.

Mahmoud, B.S.M., N.A. Vaidya, C.M. Corvalan, and R.H. Linton. 2008. Inactivation kinetics of inoculated Escherichia coli O157: H7, Listeria monocytogenes and Salmonella Poona on whole cantaloupe by chlorine dioxide gas. Food Microbiol. 25:857-865.

Mahovic, M.J., J.D. Tenney, and J.A. Bartz. 2007. Applications of chlorine dioxide gas for control of bacterial soft rot in tomatoes. Plant Dis. 91:1316-1320.

Murphy, M.M., L.M. Barraj, and G.C. Rampersaud. 2014. Consumption of grapefruit is associated with higher nutrient intakes and diet quality among adults, and more favorable anthropometrics in women, NHANES 2003-2008. Food Nutr. Res. 58:1-11. W.W. Widmer. 2012. Effect of copper hydroxide sprays for citrus canker control on wildtype Escherichia coli. Lett. Appl. Microbiol. 54:108-111.

Netramai, S., M. Rubino, and R. Auras. 2012. Compatibility of chlorine dioxide as antimicrobial gas for food packaging application. Ital. J. Food Sci. 24:59-62.

Okull, D.O., A. Demirci, D. Rosenberger, and L.F. LaBorde. 2006. Susceptibility of Penicillium explansum spores to sodium hypochlorite, electrolyzed oxidizing water, and chlorine dioxide solutions modified with nonionic surfactants. J. Food Prot. 69:1944-1948.

Reddy, P.J., D.R. Ellington, Y. Zhu, and K.F. Browne. 2007. The safety of grapefruit juice in patients taking atorvastatin. Circulation 115:E265.

Rodgers, S.L., J.N. Cash, M. Siddiq, and E.T. Ryser. 2004. A comparison of different chemical sanitizers for inactivating Escherichia coli O157: H7 and Listeria monocytogenes in
Narciso, J.A., C.M. Ference, M.A. Ritenour, and 
solution and on apples, lettuce, strawberries, and cantaloupe. J. Food Prot. 67:721-731.

Ruparelia, J.P., A.K. Chatteriee, S.P. Duttagupta, and S. Mukherji. 2008. Strain specificity in antimicrobial activity of silver and copper nanoparticles. Acta Biomater. 4:707-716.

Singh, N., R.K. Singh, A.K. Bhunia, and R.L. Stroshine. 2002. Efficacy of chlorine dioxide, ozone, and thyme essential oil or a sequential washing in killing Escherichia coli O157: H7 on lettuce and baby carrots. Lebensm. Wiss. Technol. 35:720-729.

Sun, X.X., J.H. Bai, C. Ference, Z. Wang, Y.F. Zhang, J. Narciso, and K.Q. Zhou. 2014. Antimicrobial activity of controlled-release chlorine dioxide gas on fresh blueberries. J. Food Prot. 77:1127-1132.
Sy, K.V., K.H. McWatters, and L.R. Beuchat. 2005a. Efficacy of gaseous chlorine dioxide as a sanitizer for killing Salmonella, yeasts, and molds on blueberries, strawberries, and raspberries. J. Food Prot. 68:1165-1175.

Sy, K.V., M.B. Murray, M.D. Harrison, and L.R. Beuchat. 2005b. Evaluation of gaseous chlorine dioxide as a sanitizer for killing Salmonella, Escherichia coli O157: H7, Listeria monocytogenes, and Yeasts and molds on fresh and fresh-cut produce. J. Food Prot. 68:1176-1187.

Trainor, E., M. Iturriza-Gomara, B. Ngwira, and N. Cunliffe. 2016. Detection of enterotoxigenic E-coli in hospitalised children with and without diarrhoea in Blantyre, Malawi. Paediatr. Intl. Child Health 36:102-105.
Vanamala, J., L. Reddivari, K.S. Yoo, L.M. Pike, and B.S. Patil. 2006. Variation in the content of bioactive flavonoids in different brands of orange and grapefruit juices. J. Food Compos. Anal. 19:157-166.

Wang, Z., J. Narciso, A. Biotteau, A. Plotto, E. Baldwin, and J.H. Bai. 2014. Improving storability of fresh strawberries with controlled release chlorine dioxide in perforated clamshell packaging. Food Bioprocess Technol. 7:3516-3524.

Zhao, W., J. Bai, G. McCollum, and E. Baldwin. 2015. High incidence of preharvest colonization of Huanglongbing-symptomatic citrus sinensis fruit by Lasiodiplodia theobromae (Diplodia natalensis) and exacerbation of postharvest fruit decay by that fungus. Appl. Environ. Microbiol. 81:364-372. 